\title{
Aetiology of uveitis in Sierra Leone, west Africa
}

Marjolein J H Ronday, Jan S Stilma, Robert F Barbe, Wilbur J McElroy, Leny Luyendijk, Arend H J Kolk, Margreet Bakker, Aize Kijlstra, Aniki Rothova
Netherlands

Ophthalmic Research Institute, Amsterdam, the Netherlands

M J H Ronday

L Luyendijk

A Kijlstra

A Rothova

F C Donders Institute of Ophthalmology,

Utrecht, the

Netherlands

J S Stilma

A Rothova

Baptist Eye Hospital, Lunsar, Sierra Leone R F Barbe

W J McElroy

Department of

Biomedical Research, Royal Tropical Institute, Amsterdam, the Netherlands A H J Kolk

Humane Retrovirology Laboratory, Academic Medical Centre, Amsterdam, the Netherlands

M Bakker

Correspondence to: Marjolein J H Ronday, MD, Netherlands Ophthalmic Research Institute, Department of Ophthalmo-Immunology, PO Box 12141, 1100 AC Amsterdam, the Netherlands.

Accepted for publication 16 September 1996

\begin{abstract}
Background-In 1992, non-onchocercal uveitis caused $9 \%$ of blindness, $8 \%$ of visual impairment, and $11 \%$ of uniocular blindness among patients visiting an eye hospital in Sierra Leone, west Africa. The aim of this study was to determine the aetiology of uveitis in this population. Methods-General and ophthalmic examination complemented by serum and aqueous humour analyses for various infectious agents was performed for 93 uveitis patients and compared with serum $(n=100)$ and aqueous humour $(n=9)$ analysis of endemic controls.
\end{abstract}

Results-At the initial examination, 45 patients $(48 \%)$ proved to be severely visually handicapped. After clinical and laboratory analyses, an aetiological diagnosis was established for 49 patients (52\%). Toxoplasma gondii was the most important cause of uveitis (40/93; 43\%). Anti-toxoplasma IgM antibodies were detected in serum samples of seven of 93 patients $(8 \%)$ compared with one of 100 controls $(1 \%$, p<0.05). At least six patients $(15 \%)$ with ocular toxoplasmosis had acquired the disease postnatally. Antibodies against Treponema pallidum were detected in 18 of 92 patients $(20 \%)$ and in 21 controls $(21 \%)$. Other causes of uveitis were varicella zoster virus (one patient), herpes simplex virus (two patients), and HLA-B27 positive acute anterior uveitis with ankylosing spondylitis (one patient), while one patient had presumed HTLV-I uveitis.

Conclusions-In a hospital population in Sierra Leone, west Africa, uveitis was associated with severe visual handicap and infectious diseases. Toxoplasmosis proved to be the most important cause of the uveitis. Although the distribution of congenital versus acquired toxoplasmosis in this population could not be determined, the results indicate an important role of postnatally acquired disease. The results further suggested minor roles for HIV, tuberculosis, toxocariasis, and sarcoidosis as causes of uveitis in this population.

(Br F Ophthalmol 1996;80:956-961)

Uveitis, an intraocular inflammation involving the uveal tract and the adjacent structures, is estimated to account for $10 \%$ of severe visual handicaps in the Western world. ${ }^{1}$ In approximately $40-50 \%$ of patients living in moderate climates an underlying systemic disease is found. ${ }^{23}$ This association could be even greater in parts of Africa where associated parasitic, viral, and fungal diseases are highly endemic. ${ }^{4}$ However, data on uveitis from these parts of the world are scarce. ${ }^{56}$ In an eye hospital in Sierra Leone $24 \%$ of blindness among new patients seen in 1992 proved to be caused by uveitis $-15 \%$ of onchocercal origin and $9 \%$ of non-onchocercal origin. ${ }^{7}$ The aetiology of uveitis in the latter group was unknown, since local laboratories were not equipped to perform the necessary diagnostic tests. These patients are at risk of receiving inadequate treatment which can result in increased morbidity, mortality, and blindness. We therefore conducted a study to determine the most frequent causes of uveitis in this region, using laboratory techniques to detect intraocular antibody production against various infectious agents.

\section{Materials and methods}

SETTING

Sierra Leone is a small country in west Africa, with four ophthalmologists for 4.5 million inhabitants. It is ranked among the 47 least developed countries in the world. ${ }^{8}$ The climate is marked by a wet season from May to October followed by a dry season from November to April, with an average annual temperature of $27^{\circ} \mathrm{C}$. Major health problems include infectious diseases such as helminthiasis, gastroenteritis, measles, tuberculosis, schistosomiasis, and leprosy. The Baptist Eye Hospital in Lunsar is one of four eye clinics and serves an area of approximately 32000 $\mathrm{km}$ where onchocerciasis or river blindness is endemic. Until 1992 basic eye care in rural areas was non-existent. A mobile team from the hospital does visit certain remote areas, but usually refers patients for cataract or glaucoma operations only. This suggests that many patients visited the hospital on their own initiative rather than through referral.

PATIENTS AND METHODS IN SIERRA LEONE

General and ophthalmic examinations complemented by serum and aqueous humour analyses for various infectious agents were performed for 93 patients with uveitis and compared with serum $(n=100)$ and aqueous humour ( $n=9)$ analyses of endemic controls. Patients over 13 years of age with active uveitis examined between February and April 1992 and between February and May 1993 were informed about the study and given the possibility to participate. Patients with uveitis caused by trauma or onchocerciasis were excluded. The research protocol was approved 
by the ethics and scientific board of the Netherlands Ophthalmic Research Institute.

The diagnosis of ocular onchocerciasis was made on clinical grounds as described by Buck.' In all new patients a skin snip was obtained to test for Onchocerca microfilariae. Patients with a positive skin snip but uveitis not in accordance with the clinical criteria of onchocerciasis were included in this study. Eighty patients were seen at the Baptist Eye Hospital in Lunsar, and 13 were seen during four visits to the eye clinic of the Kissy United Methodist Church Hospital near the capital, Freetown. All patients were seen by an ophthalmic nurse, an ophthalmologist, and the first author. Patients underwent a general physical examination and, if indicated, additional tests were performed at a nearby general hospital (for example, radiography of the lungs or sacroiliac joint). The ophthalmic examination included history, optimal visual acuity (Snellen E chart), intraocular pressure (Schiotz tonometer), slit-lamp examination, and indirect funduscopy with a $20 \mathrm{D}$ lens after dilatation. Blindness was defined as visual acuity less than $3 / 60$ in the better eye and visual impairment was defined as visual acuity better than $3 / 60$ but less than $6 / 18$ in the better eye. ${ }^{10}$ Uveitis was classified using the International Uveitis Study Group classification system, which is based on anatomic localisation of inflammation. ${ }^{11}$ If possible, a clinical diagnosis was made and treatment given. The clinical diagnosis of ocular toxoplasmosis was made if an active (satellite) lesion was seen together with one or more healed, focal, pigmented retinal or chorioretinal scar(s) with well defined borders.

After the diagnostic procedures had been explained again to the patient and informed consent had been obtained, a venepuncture and aqueous humour paracentesis were performed on the same or the next day. Serum was obtained from $10 \mathrm{ml}$ of venous blood which was left to clot for 1 hour and centrifuged for 10 minutes at $3000 \times g$, subdivided, and stored frozen. The aqueous humour sample was collected under sterile conditions and stored frozen. ${ }^{12}$ The eye was covered with an antibiotic ointment patch and examined on the following day and, if possible, repeatedly thereafter. As a control group, 91 serum samples and nine paired serum and aqueous humour samples were obtained as described above from 100 people without uveitis (25 people from two previous studies performed at the eye hospital in Lunsar ${ }^{1314}$ and 75 patients visiting the hospital during this study, nine of whom underwent intraocular surgery for cataract or glaucoma). All samples were transported frozen to the Netherlands Ophthalmic Research Institute for analysis. Laboratory results were sent to the eye hospital and to the patients' home address (if available).

LABORATORY METHODS IN THE NETHERLANDS (TABLE 1)

Firstly, serum samples from patients and controls were screened for IgG antibodies against Toxoplasma gondii (immunofluores- cence test, Behringwerke AG, Marburg, Germany), Toxocara canis, ${ }^{15}$ herpes simplex virus (HSV), varicella zoster virus (VZV), cytomegalovirus (CMV), and Epstein-Barr virus (EBV) (immunofluorescence tests for VZV, HSV, CMV, and EBV, Gull Laboratories, Salt Lake City, USA), and Treponema pallidum (Serodia-TP haemagglutination test, Fujirebio Inc, Tokyo, Japan). In case of a positive result in a patient's serum sample, the paired serum and aqueous humour samples of this patient were tested simultaneously to determine possible intraocular antibody production, calculated by the Goldmann-Witmer coefficient $(C)^{16}$ as described previously. ${ }^{17} \mathrm{~A}$ coefficient $\mathrm{C}$ greater than or equal to 3 was considered to indicate local antibody production. The ratio of coefficients for two different infectious entities was calculated to rule out possible false positive results from aspecific polyclonal B cell activation. ${ }^{18}$ The samples collected in 1993 (44 patients) were not tested for intraocular antibody production against $T$ pallidum and $T$ canis because of negative results in the aqueous humour samples from patients collected in 1992. Instead, patients seen in 1993, who were suspected of having syphilitic uveitis, were treated with high doses of intramuscular penicillin. Paired serum and aqueous humour samples from nine controls were tested for intraocular antibody production against $T$ gondii.

Serum samples from patients and controls were also tested for anti-toxoplasma IgM antibodies (IgM capture ELISA, Alfa Biotech, Rome, Italy), and for IgG antibodies against HIV types 1 and 2 (HIV 3.0 plus EIA, Abbott, Wiesbaden-Delkenheim, Germany; positive results were confirmed by western blot), against human $T$ cell lymphotropic virus type $I$ (HTLV-I EIA, Abbott, WiesbadenDelkenheim, Germany; positive results were confirmed by western blot), against Mycobacterium tuberculosis (ELISA assay sensitivity and specificity $93 \%$ and $100 \%$, respectively), ${ }^{19}$ and against Neisseria gonorrhoea. ${ }^{20}$ Serum angiotensin converting enzyme activity was determined by the colorimetric method (ACEcolor kit, Fujirebio Inc, Tokyo, Japan), with the adaptation of raising the standard cut off level of $50 \mathrm{U} / 1$ (mean Dutch controls $+2 \mathrm{SD}$ ) to 70 $\mathrm{U} / \mathrm{l}$ (mean of 93 skin snip negative endemic controls +2 SD). Serology for $M$ tuberculosis and $N$ gonorrhoea was not performed in 1993 because of the negative results in patients' samples collected in 1992. Only a proportion of the control group with similar age and sex characteristics as the patient group was tested in the HSV, VZV, CMV, EBV, $M$ tuberculosis, and $N$ gonorrhoea assays (Table 1 ).

A definitive diagnosis of ocular toxoplasmosis was made if intraocular antibody analysis yielded a Goldmann-Witmer coefficient (C) greater than 3. Ocular toxoplasmosis was presumed if a clinical diagnosis had been made, serum antibodies were present, but intraocular antibody production could not be detected $(C<3)$. Toxoplasmosis was presumed to be postnatally acquired in cases of a focal retinitis with a high serum anti- 
Table 1 Results of serum and aqueous humour analyses of patients with uveitis and controls from Sierra Leone

\begin{tabular}{|c|c|c|c|c|c|c|c|c|}
\hline \multirow[b]{3}{*}{ Entity } & \multicolumn{4}{|c|}{ Specific serum antibodies } & \multicolumn{4}{|c|}{ Specific intraocular antibody production * } \\
\hline & \multicolumn{2}{|l|}{ Patients } & \multicolumn{2}{|l|}{ Controls } & \multicolumn{2}{|l|}{ Patients } & \multicolumn{2}{|l|}{ Controls } \\
\hline & $\begin{array}{l}\text { Number } \\
\text { tested }\end{array}$ & Positive (\%) & $\begin{array}{l}\text { Number } \\
\text { tested }\end{array}$ & Positive (\%) & $\begin{array}{l}\text { Number } \\
\text { tested }\end{array}$ & Positive (\%) & $\begin{array}{l}\text { Number } \\
\text { tested }\end{array}$ & Positive (\%) \\
\hline Toxoplasma gondii (IgG) & 93 & $80(86)$ & 100 & $77(77)$ & 93 & $28(30)$ & 9 & 0 \\
\hline Toxoplasma gondii (IgM) & 93 & $7(8) \dagger$ & 100 & $1(1) t$ & ND & NA & ND & NA \\
\hline Toxocara canis & $49 \ddagger$ & $3(6)$ & ND & NA & 3 & 0 & ND & NA \\
\hline Herpes simplex virus & $93^{\top}$ & $92(99)$ & 24 & $24(100)$ & 93 & $2(2)$ & ND & NA \\
\hline Varicella zoster virus & 93 & $93(100)$ & 24 & $24(100)$ & 93 & $1(1)$ & ND & NA \\
\hline Cytomegalovirus & 93 & $92(99)$ & 24 & $24(100)$ & 93 & 0 & ND & NA \\
\hline Epstein-Barr virus & 93 & $93(100)$ & 24 & $24(100)$ & 93 & 0 & ND & NA \\
\hline HIV type 1 & 93 & $1(1)$ & 410 & 0 & ND & NA & ND & NA \\
\hline HIV type 2 & 93 & 0 & $41 \S$ & 0 & ND & NA & ND & NA \\
\hline HTLV-I & 93 & $6(7)$ & 100 & $5(5)$ & ND & NA & ND & NA \\
\hline Treponema pallidum & 92 & $18(20)$ & 100 & $21(21)$ & 11 & 0 & ND & NA \\
\hline$M$ tuberculosis & $49 \ddagger$ & 0 & 36 & 0 & ND & NA & ND & NA \\
\hline$N$ gonorrhoea & $49 \ddagger$ & 0 & 15 & $1(7)$ & ND & NA & ND & NA \\
\hline Angiotensin converting enzyme & 93 & $4(4)$ & 939 & $4(4)$ & NA & NA & ND & NA \\
\hline
\end{tabular}

$\star$ Goldmann-Witmer coefficient $\geq 3$; tp<0.05; †only samples of patients seen in 1992 tested ( $n=49$ ); Sendemic controls with proved pulmonary tuberculosis; serum angiotensin converting enzyme activity $>70 \mathrm{U} / \mathrm{l}$ was considered positive; fendemic controls without uveitis or onchocerciasis; ND = not done; NA = not applicable.

toxoplasma IgG titre $(\geq 1: 1024)$ and specific IgM, a short history of uveitis, and no previous scars in either eye. ${ }^{21}$ One case of bilateral anterior uveitis was attributed to toxoplasmosis because of a very high anti-toxoplasma IgG serum titre (1:16 000) and specific serum IgM antibodies.

For statistical analyses the $\chi^{2}$ test was used, and $\mathrm{p}<0.05$ was considered to be significant.

\section{Results}

PATIENT CHARACTERISTICS

A total of 93 patients and 100 endemic controls from Sierra Leone were enrolled in the study. Twenty patients came from neighbouring countries-19 from Guinea and one from Liberia. In the control group eight patients came from Guinea. The mean age of the patients was 36 years (SD 14, range 14-67 years), with a male to female ratio of $1: 0.7$. The mean age of the 100 controls was 38 years (SD 15 , range $12-70$ years) with a male to female ratio of 1:0.8. A skin snip positive for Onchocerca microfilariae was found in seven patients and seven controls.

\section{HISTORY}

'Dim vision' was the most important reason for visiting the hospital $(90 \%)$; 'pain and redness of the eye' was reported by only nine patients $(10 \%)$ as the most important complaint. In the majority of the patients the symptoms had existed for 3 months or more $(60 \%)$. Fifty seven patients experienced a first attack, 32 had more than one episode of uveitis, eight of which said to have had recurrent attacks. In four patients the number of episodes was unknown.

OCULAR FINDINGS

In the 93 patients, uveitis was unilateral in $\mathbf{5 7}$ and bilateral in 36 , yet bilaterally active in only five patients. Most patients presented with panuveitis $(51 ; 55 \%)$; posterior uveitis was presented by 21 patients (23\%), anterior uveitis by $17(18 \%)$, and intermediate uveitis by four (4\%). At presentation, 29 patients $(31 \%)$ had one or more complications, including cataracts (20 patients), glaucoma (eight patients), vitre- ous haemorrhage (three patients), and retinal detachment (two patients). Ten patients (11\%) were bilaterally blind and 13 patients (14\%) were visually impaired. Another 22 patients (24\%) were blind in one eye. Aqueous humour sampling yielded 100-200 $\mu \mathrm{l}$ of fluid and was not associated with complications except for a small hyphaema in two patients with iritis and an intraocular pressure over $20 \mathrm{~mm} \mathrm{Hg}$.

DIAGNOSIS AFTER SERUM AND AQUEOUS HUMOUR ANALYSES

Overall, from the total of 93 uveitis patients in Sierra Leone, the aetiological diagnosis of uveitis could be established in 49 patients (52\%) - that is, a proved laboratory diagnosis in 32 patients and a clinical diagnosis in 17 patients (Table 2).

For patients with posterior uveitis or panuveitis, the diagnosis could be determined in 46 of $72(64 \%)$, compared with only two of 17 $(12 \%)$ with anterior uveitis. Of 15 patients with anterior uveitis without a detectable aetiological diagnosis, seven had laboratory findings within normal limits. Of the remaining eight patients one had a positive skin snip test but uveitis not typical for onchocercal infection, two patients had elevated serum angiotensin converting enzyme activity (83 and $71 \mathrm{U} / 1$, respectively; one also had HTLV-I type antibodies), two had HLTV-I antibodies, and three had antibodies against $T$ pallidum.

The results of serum and aqueous humour analyses for several uveitis entities are shown in Table 1 and are described in more detail below.

Table 2 Aetiological diagnosis of 93 patients with uveitis from Sierra Leone

\begin{tabular}{llll}
\hline Diagnosis & Laboratory & Clinical & Total \\
\hline $\begin{array}{l}\text { Toxoplasmosis } \\
\text { Herpes simplex }\end{array}$ & $28^{\star}$ & 12 & 40 \\
$\quad$ virus & $2^{\star}$ & - & 2 \\
$\begin{array}{l}\text { Varicella zoster } \\
\quad \text { virus }\end{array}$ & $1^{\star}$ & - & 1 \\
HTLV-I & - & 1 & 1 \\
Syphilis & - & 4 & 4 \\
$\begin{array}{l}\text { Ankylosing } \\
\quad \text { spondylitis }\end{array}$ & $1 \dagger$ & - & 1 \\
Total (n=93) (\%) & $32(34)$ & $17(18)$ & $49(52)$ \\
\hline
\end{tabular}

${ }^{\star}$ Goldmann-Witmer coefficient $\geq 3$; †confirmed by radiography; - = 'none'. 
Table 3 Clinical findings in patients with ocular toxoplasmosis

\begin{tabular}{llll}
\hline & Laboratory diagnosis ${ }^{*}(n=28)$ & Clinical diagnosist $(n=12)$ & Total $(n=40)$ \\
& No (\%) & No (\%) & No (\%) \\
\hline $\begin{array}{l}\text { Posterior and } \\
\text { panuveitis }\end{array}$ & $28(100)$ & $11(92)$ & $39(98)$ \\
$\begin{array}{l}\text { Anterior uveitis } \\
\begin{array}{l}\text { Unilateral } \\
\text { involvement }\end{array}\end{array}$ & - & 1 & 1 \\
Bilateral involvement & $12(43)$ & $6(50)$ & $22(55)$ \\
\hline
\end{tabular}

*Goldmann-Witmer coefficient for toxoplasmosis $\geq 3$; †Goldmann-Witmer coefficient for toxoplasmosis $<3$; $\ddagger$ including 17 patients with an active lesion in one eye and one or more scars in the opposite eye, and one patient with bilaterally active anterior uveitis.

\section{Parasites}

Toxoplasmosis Anti-toxoplasma IgG antibodies were detected in serum samples from 80 patients $(86 \%)$ and 77 controls $(77 \%)$, while anti-toxoplasma IgM antibodies were detected in serum samples from seven patients (8\%) and one control $(1 \% ; p<0.05)$. Ocular toxoplasmosis was diagnosed in 40 patients (43\%); this included 28 patients with a proved laboratory diagnosis (positive GoldmannWitmer coefficient (median 11.4, range 3.2 to 401)) and 12 patients with a clinical diagnosis (Goldmann-Witmer coefficient $<3$ ). Of these 12 patients, four had presumed acquired ocular toxoplasmosis. The ocular features of patients with ocular toxoplasmosis are shown in Table 3. Overall, intraocular antibody analysis confirmed a clinical diagnosis of ocular toxoplasmosis in 15 of 24 patients (63\%), while in 13 of 69 patients (19\%) without a clinical diagnosis of ocular toxoplasmosis intraocular antibody analysis revealed the diagnosis. Intraocular antibody production against $T$ gondii could not be demonstrated in nine controls with cataracts or glaucoma.

Toxocariasis Of all 49 patients seen in 1992, three had serum antibodies against Toxocara canis. None of these patients had clinical ocular toxocariasis and no specific intraocular antibody production was detected.

\section{Viruses}

IgG antibodies against $\mathrm{HSV}, \mathrm{VZV}, \mathrm{CMV}$, and EBV were detected in almost all serum samples from both patients and controls (Table 1). Intraocular antibody production against $\mathrm{HSV}$ was demonstrated in two patients $(2 \%)$ with panuveitis, while local antibody production against VZV was found in one patient (1\%) with posterior uveitis. None of these patients showed the clinical features consistent with a diagnosis of acute retinal necrosis. Local antibody production against $\mathrm{CMV}$ or EBV could not be demonstrated.

Antibodies against HTLV-I were detected in the serum samples from six patients $(7 \%)$ and five controls (5\%). For one HTLV-I seropositive patient with intermediate uveitis and vitreous opacities the presumed diagnosis of HTLV-I uveitis was made. ${ }^{22}$ In four patients with positive HLTV-1 serology a different cause of uveitis was found (toxoplasmosis (three patients), and HSV (one patient)).

Antibodies against HIV-1 were detected in one patient $(1 \%)$. The patient was diagnosed with presumed ocular toxoplasmosis and did not have any clinical signs of immunodefi- ciency. Two patients had a positive result in the HIV-1/HIV-2 assay but an indeterminate western blot and were not clinically immunocompromised.

\section{Bacteria}

Syphilis Antibodies against $T$ pallidum were detected in serum samples from 18 of 92 patients $(20 \%$; one patient with ocular toxoplasmosis was not tested because of a limited amount of serum) and in serum samples from 21 controls $(21 \%)$. Intraocular antibody production could not be demonstrated (Table 1). The diagnosis of presumed syphilitic uveitis was made for four patients on the basis of their history and clinical features and/or rapid recovery after specific treatment, and laboratory investigations which did not reveal any other cause of uveitis.

Tuberculosis One patient was clinically suspected of having tuberculous uveitis. He developed panuveitis in his left eye after cataract extraction and had small choroidal tuberculous lesions in the right eye. He was started on a treatment trial with isoniazid but did not return for follow up. Based on their history and symptoms, five patients had chest radiography; however, no abnormalities were seen. Furthermore, none of the 49 patients seen in 1992 proved to be positive in the tuberculosis ELISA.

\section{Presumed non-infectious disease}

Sarcoidosis Four patients had increased serum angiotensin converting enzyme activity (> $70 \mathrm{U} / \mathrm{l}$ ). However, chest radiographs of these patients were not available. One patient had proved ocular toxoplasmosis, one patient had serum antibodies against $T$ pallidum, one patient had serum antibodies against HTLV-I, while one patient had test results within the normal limits. She had acute anterior uveitis with fine keratic precipitates, a few cells but marked flare in the anterior chamber, and no systemic features consistent with the diagnosis of sarcoidosis.

Ankylosing spondylitis Recurrent alternating anterior uveitis with extremely limited spinal mobility, lumbar lordosis, kyphosis, and a forward slope of the neck was encountered in a 33-year-old man from Guinea. Ankylosing spondylitis was confirmed by radiography of the sacroiliac joint. The patient had suffered from attacks of uveitis for 4 years which had left him with only light perception in one eye. After lens extraction and a large iridectomy his visual acuity improved to walking vision. His deceased father had suffered from the same symptoms. The family belonged to the Fullah tribe and did not have any (known) white ancestors. The patient proved to be positive for the HLA-B27 antigen.

\section{Discussion}

Overall, a specific laboratory or clinical diagnosis could be established for 49 (52\%) of the 93 patients with uveitis examined in Sierra Leone. The most important cause of uveitis in this population was toxoplasmosis, occurring in $\mathbf{4 0}$ of 93 patients. 
Most patients presented with panuveitis (55\%) or posterior uveitis $(23 \%)$ compared with $20 \%$ and $17 \%$, respectively, in a Dutch hospital population. ${ }^{3}$ In a poor region where one has to travel far for eye care, it is obvious that people postpone a journey until their eyesight has become extremely poor. Patients whose only complaints were pain and redness of the eye came from villages close to the hospital. A total of 45 patients (48\%) had already become blind in one eye or in both eyes, or had become visually impaired. It is therefore important to stimulate the training of ophthalmic nurses to provide basic eye care in the region.

Recurrent anterior uveitis occurred in only three of 17 patients with anterior uveitis, including the HLA-B27 positive patient with ankylosing spondylitis. Unfortunately, HLA typing of all patients was not possible. Reports on the frequency of HLA-B27 in Africa vary from $9.7 \%$ in Mali and $2.6 \%$ in Gambia, to nearly zero in Nigerians and South African blacks. ${ }^{23}$

The use of intraocular antibody analysis greatly contributes to the diagnosis of toxoplasmic and viral uveitis and is considered to be a safe and helpful procedure for the diagnosis of uveitis. ${ }^{12}$ In approximately 300 patients with uveitis in whom paracentesis was performed by experienced ophthalmologists, no (long term) complications were seen (Van der Lelij et al, submitted). In our study, two patients developed a small hyphaema in the anterior chamber immediately following aqueous humour paracentesis. Both eyes had increased pressure and iritis. Since the hyphaemas cleared completely within 2 days, we believe no lasting damage was done to either eye. However, we conclude that an aqueous humour tap should preferably be performed in eyes with a normal intraocular pressure.

Our results clearly showed that ocular toxoplasmosis was the most important cause of uveitis in this west African population. This finding is in agreement with a recent study from south London where an incidence of acute symptomatic Toxoplasma retinochoroiditis of $0.4 / 100000 /$ year was found for people born in Britain compared with 57/100 000/ year for black people born in west Africa who moved to Britain during their adolescence. ${ }^{24}$ Previous reports from Nigeria ${ }^{6}$ and on west African immigrants in London ${ }^{2526}$ also suggested an important role of Toxoplasma as a cause of uveitis. Our study confirms the clinical diagnosis of Toxoplasma retinochoroiditis in Sierra Leone, using the detection of intraocular antibody production. While the presence of chorioretinal scars, especially in the opposite eye, was an important factor to establish the clinical diagnosis of toxoplasmosis, 16 of 28 patients $(57 \%)$ with intraocular antibody production against $T$ gondii had no scars in the opposite eye, while five patients $(18 \%)$ did not have any scars at all. The only consistent feature in the patients with toxoplasmosis was focal retinochoroiditis, with the exception of one HIV negative patient with bilateral anterior uveitis and laboratory results indicating recently acquired toxoplasmosis. So far, only one case of unilateral anterior toxoplasma uveitis has been reported in an AIDS patient. ${ }^{27}$ Our patient had a very high anti-toxoplasma IgG serum titre which may have concealed any specific intraocular antibody production, resulting in a false negative Goldmann-Witmer coefficient. ${ }^{17}$ The distribution of congenital versus acquired toxoplasmosis could not be determined in this study. At least six patients $(6 / 40 ; 15 \%)$ acquired the disease postnatally; four patients had specific IgM antibodies, high serum IgG antibodies, a short duration of the ophthalmic complaints, and an absence of chorioretinal scars; while the aqueous humour analysis of two siblings also indicated postnatal transmission of the disease. A population based household survey as performed in southern Brazil, where acquired toxoplasmosis was found to be an important cause of retinochoroiditis, would be needed to clarify this issue. $^{28}$ The mode of transmission of Toxoplasma in Sierra Leone is probably through contaminated soil and ground water, ${ }^{29}$ since the diet does not include raw or uncooked meat. Possible explanations for the high frequency of ocular toxoplasmosis may include either (repeated infections with) a more virulent strain, genetic or host differences, or the interactions of coinfections altering the course of the disease.

Antibodies against HSV, VZV, CMV, and EBV were found in serum samples of almost all patients and controls. However, in only three patients intraocular antibody production against HSV or VZV was detected. HTLV-I associated uveitis has only been reported from Japan where HLTV-I infection is endemic. ${ }^{22}$ Although $5 \%$ of both patients and controls had serum antibodies against HTLV-I, only one case could be related to HTLV-I infection. Reliable data on the seroprevalence of HIV in Sierra Leone are not available; however, our findings indicate a low prevalence. To confirm this conclusion, 41 patients with pulmonary tuberculosis from an adjacent general hospital were also tested in the HIV-1/2 assay with a negative result in all cases (data not shown). The large number of both patients and controls positive in the $T$ pallidum haemagglutination test was a remarkable finding. Unfortunately, the laboratory tests available for syphilis are not able to distinguish between $T$ pallidum subspecies pallidum ('venereal syphilis') and $T$ pallidum subspecies endemicum ('endemic syphilis' or 'bejel'). We believe that it is the latter organism which had infected most of our patients and controls, since other sexually transmitted diseases such as HIV and gonorrhoea were virtually absent. Endemic syphilis only occurs in hot and dry climates, and is transmitted non-sexually. Most infections occur during childhood by sharing spoons and cups. Like venereal syphilis, the endemic type consists of three phases, apart from late cardiovascular or neurological manifestations. Data on the relation between endemic syphilis and uveitis have only been reported from Saudi Arabia. ${ }^{30}$ Of the four patients in our study suspected of having 
syphilitic uveitis only two had a history pointing to the venereal type of the disease; in the other two the diagnosis was presumed because of the rapid improvement after penicillin therapy. The evaluation of anti-Treponema pallidum antibodies in the aqueous humour of 11 patients with specific serum antibodies did not contribute to the diagnosis of syphilitic uveitis, a finding reported earlier. ${ }^{31}$

The absence of uveitis caused by tuberculosis was unexpected. Since no patient had a history of tuberculosis, we performed an assay to detect serum IgG antibodies against $M$ tuberculosis. Although $93 \%$ of patients with endemic tuberculosis proved to be positive, none of the uveitis patients did. We did not perform tuberculin skin testing since most people in this area had been vaccinated. Reports from Europe and the USA from the first half of this century mostly showed large numbers of tuberculous uveitis. ${ }^{32}$ However, more recent reports indicate that tuberculosis might not involve the eye as frequently as previously believed. ${ }^{33}$ The recent development of the polymerase chain reaction test for the detection of $M$ tuberculosis in ocular fluid or tissue offers great potential for the diagnosis of ocular tuberculosis ${ }^{34}$ (Ronday et al, in preparation).

In our study, the diagnosis of sarcoidosis could not be made. Although elevated serum angiotensin converting enzyme activity was measured in three (skin snip negative) patients with idiopathic uveitis, no chest radiographs or biopsies were available from these patients to confirm the diagnosis of sarcoidosis. An isolated finding of elevated serum angiotensin converting enzyme activity cannot confirm the diagnosis of sarcoidosis in this area, since angiotensin converting enzyme levels can also be raised as a result of other granulomatous diseases such as tuberculosis, leprosy, schistosomiasis, and onchocerciasis. ${ }^{3536}$ However, the possibility of sarcoidosis cannot be ruled out entirely. Uveitis caused by leprosy was not encountered in this study. All leprosy patients were taken care of in a special hospital nearby.

From the results described above we conclude that uveitis in Sierra Leone is often associated with severe visual handicaps and infectious disease. The most important cause was toxoplasmosis, especially in cases with focal chorioretinitis. Since one of five people had serological evidence of a syphilis infection, this diagnosis should also be considered. An early and accurate diagnosis could prevent blindness and improve general health in these patients.

We gratefully acknowledge the patients and staff of the Baptist Eye Hospital in Lunsar and the Kissy UMC Hospital for their participation and cooperation; Gonnie van der Lelij and Suzy Njoo for the provided serum control samples; Marian Junior Lardy for their technical assistance; and Mrs G E E van Noppen for reviewing the manuscript.

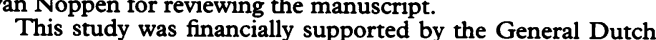
This study was financially supported by the General Dutch
Foundation for the Prevention of Blindness and the Dr F P Fisher Foundation, the Netherlands.

1 Nussenblatt RB. The natural history of uveitis. Int Ophthalmol 1990;14:303-8.

2 Rosenbaum JT. Uveitis. An internist's view. Arch Intern Med 1989;149:1173-6.
3 Rothova A, Buitenhuis HJ, Meenken C, Brinkman CJJ, Linssen A, Alberts C, et al. Uveitis and systemic disease. $\mathrm{Br} f$ Ophthalmol 1992;76:137-41.

4 World Health Organisation. Expert committee on onchocerciasis. Fourth report. WHO Tech Rep Ser 1995;852:25-30.

5 Rodger FC. Blindness in west Africa. London: HK Lewis, 1959.

6 Ayanru JO. The problem of uveitis in Bendel State of Nigeria: experience in Benin City. $\mathrm{Br} \mathcal{f}$ Ophthalmol 1977;61:655-9.

7 Ronday MJH, Stilma JS, Barbe RF, Kijlstra A, Rothova A. Blindness from uveitis in a hospital population in Sierra Leone. Br f Ophthalmol 1994;78:690-3.

8 Development Co-operation. Efforts and politics of the members of the Development Assistant Committee. Development 1995.

9 Buck AA. Onchocerciasis: symptomatology, pathology, diagnosis. Geneva: WHO, 1974

10 WHO methods of assessment of avoidable blindness. Geneva: WHO offset publication No 54. 1980.

11 Bloch-Michel E, Nussenblatt RB. International uveitis study group recommendations for the evaluation of intraocular inflammatory disease. Am f Ophthalmol 1987;103:234-5.

12 de Boer JH, Luyendijk L, Rothova A, Kijlstra A. Analysis of ocular fluids for local antibody production in uveitis. $\mathrm{Br} \mathcal{F}$ Ophthalmol 1995;79:610-6.

13 Van der Lelij A, Doekes G, Hwan BS, Vetter JCM, Rietveld E, Stilma JS, et al. Humoral autoimmune response against S-antigen and IRBP in ocular onchocerciasis. Invest Ophthalmol Vis Sci 1990;31:1374-80.

14 Njoo Fl, Hack CE, Oosting J, Stilma JS, Kijlstra A. Neutrophil activation in ivermectin-treated onchocerciasis patients. Clin Exp Immunol 1993;94:330-3.

15 Knapen F van, Leusden J van, Polderman AM, Franchimont JH. Visceral larvae migrans: examinations by means of enzyme-linked immunosorbent assay of human sera for antibodies to excretory-secretory antigens of the secondstage larvae of Toxocara canis. Zeitschrift für Parasitenkunde 1983;69:113-8.

16 Goldmann H, Witmer R. Antikörper im kammerwasser. Ophthalmologica 1954;127:323-30.

17 de Boer JH, Luyendijk L, Rothova A, Baarsma GS, de Jong PTVM, Bollemeijer JG, et al. Detection of intraocular antibody production to herpesviruses in acute retinal necrosis syndrome. Am $\mathcal{F}$ Ophthalmol 1994;117:201-10.

18 Dussaix E, Cerqueti PM, Pontet F, Bloch-Michel E. New approaches to the detection locally produced antiviral antibodies in the aqueous of patients with endogenous uveitis. Ophthalmologica 1987;194:145-9.

19 Verbon A, Weverling GJ, Kuijper S, Speelman P, Jansen HM, Kolk AHJ. Evaluation of different tests for the serodiagnosis of tuberculosis and the use of likelihood ratios in serology. Am Rev Resp Dis 1993;148:378-84.

20 Young $\mathrm{H}$, Low AC. Serological diagnosis of gonorrhoea: detection of antibodies to gonococcal pili by enzyme-linked immunosorbent assay. Med Lab Sci 1981;38:41-7.

21 Ronday MJH, Luyendijk L, Baarsma GS, Bollemeijer JG Van der Lelij A, Rothova A. Presumed acquired ocular toxoplasmosis. Arch Ophthalmol 1995;113:1524-9.

22 Mochizuki $M$, Tajima $K$, Watanabe $T$, Yamaguchi $K$. Human T lymphotropic virus type I uveitis. $\mathrm{Br} \mathcal{F} O$ phthalmol 1994;78:149-54.

23 Hill AVS, Allsopp CEM, Kwiatkowski D, Anstey NM Greenwood BM, McMichael AJ. HLA class I typing by 337:640-2.

24 Gilbert RE, Stanford MR, Jackson H, Holliman RE, Sanders $\mathrm{MD}$. Incidence of acute symptomatic toxoplasma retinochoroiditis in south London according to country of birth. BMF 1995;310:1037-40.

25 Chesterton JR, Perkins ES. Ocular toxoplasmosis among immigrants in London. Br f Ophthalmol 1967;51:617-21.

26 Perkins ES. Epidemiology of uveitis. Trans Ophthalmol Soc UK 1976;96:105-7.

27 Rehder JR, Burnier M, Pavesio CE, Kim MK, Rigueiro $M$ Petrilli AMN, et al. Acute unilateral toxoplasmic iridocyclitis in an AIDS patient. Am $\mathcal{F}$ Ophthalmol 1988;106:740-1.

28 Glasner PD, Silveira C, Kruszon-Moran D, Martins MC, Burnier Jr M, Silveira S, et al. An unusually high prevalence of ocular toxoplasmosis in southern Brazil. Am $\mathfrak{F}$ Ophthalmol 1992;114:136-44.

29 Benenson MW, Takafuji ET, Lemon SM, Greenup RL, Sulzer AJ. Oocyst-transmitted toxoplasmosis with ingestion of contaminated water. $N$ Engl Med $\mathcal{F}$ 1982;307:666-9.

30 Tabbara KF, Al Kaff AS, Fadel T. Ocular manifestations of endemic syphilis (bejel). Ophthalmology 1989;96:1087-91.

31 Touboul JP, Le Hoang P, Fontaine M, Wechsler B, Cabane $\mathrm{J}$, Godeau $\mathrm{P}$, et al. Uvéites au cours de la syphilis acquise (acquired syphilitic uveitis). $\mathcal{F}$ Fr Ophtalmol 1985;8:321-31.

32 Guyton JS, Woods AC. Etiology of uveitis. Arch Ophthalmol 1941;26:983-1018.

33 Henderly DE, Genstler AJ, Smith RE, Rao NA. Changing patterns of uveitis. Am f Ophthalmol 1987;103:131-6.

34 Kotake S, Kimura K, Yoshikawa K, Sasamoto Y, Matsud A, Nishikawa T, et al. Polymerase chain reaction for the detection of Mycobacterium tuberculosis in ocular tuberculosis. Am f Ophthalmol 1994;117:805-6.

35 Studdy RP, Lapworth R, Bird R. Angiotensin-converting enzyme and its clinical significance-a review. $\mathcal{F}$ Clin Pathol 1983;36:938-47.

36 Ronday $\mathrm{MJH}$, Van $\operatorname{der}$ Lelij A, Wienesen $M$, Rothova A, Stilma JS, Kijlstra A. Elevated serum angiotensinconverting enzyme activity in onchocerciasis. Lung 1996 (in press). 